INTERDISCIPLINARIA ARCHAEOLOGICA

\title{
The Salme I Ship Burial: An Osteological View of a Unique Burial in Northern Europe
}

\author{
Raili Allmäe $\mathrm{e}^{\mathrm{a}^{*}}$, Liina Maldre ${ }^{\mathrm{a}}$, Teresa Tomek ${ }^{\mathrm{b}}$ \\ anstitute of History, Tallinn University, Rü̈̈tli 6, Tallinn 10130, Estonia \\ ${ }^{b}$ Institute of Systematics and Evolution of Animals, Polish Academy of Sciences, Sławkowska 17, 31-016 Kraków, Poland
}

\section{ARTICLE INFO}

\section{Article history:}

Received: 15 May 2011

Accepted: 20 December 2011

\section{Keywords:}

ship burial

human osteology

archaeozoology

Estonia

\begin{abstract}
In autumn 2008 human and animal bones came to light during cabling work in the village of Salme, on Saaremaa Island, Estonia. Some days later a contour of an ancient ship was discovered. The ancient ship, as well as the human and animal bones inside it, date to the second half of the $7^{\text {th }}$ century or the beginning of $8^{\text {th }}$ century, AD. Osteological analyses concentrated on specific qualities of this burial which are unknown in ship burials from the Baltic Sea and in the broader context of northern Europe. The skeletons of seven men, and bones of several domestic animals and hawks were found in the remains of the ship. The exceptional features of the Salme I ship burial are the absence of the bones of dogs and horses, which are very common in Scandinavian ship burials, and the particularly large number of men buried in one ship.
\end{abstract}

\section{Introduction}

Ship burials were wide spread in northern Europe and the British Isles at the end of the first millennium (Müller-Wille 1974), during the Vendel Era (550-800 AD) and especially during the Viking Age (800-1100 AD). Among them are the famous and richly furnished $7^{\text {th }}$ century ship burial at Sutton Hoo (Bruce-Mitford, Rupert 1979; Evans 1986; Carver 1992) and the $6^{\text {th }}$ century ship grave at Snape (Bruce-Mitford 1974; Filmer-Sankey 1992). Fields with several ship burials, such as those at Valsgärde, Tuna in Alsike, Tuna in Badelunda and Vendel in Sweden (Arwidsson 1942; 1954; 1977; Arne 1934; Stolpe, Arne 1912), are also well known. More ship burials are known from the Viking Age, with Oseberg and Gokstad in Norway (Brøgger et al. 1917; Nicolaysen 1882) and Ladby (Sorensen et al. 2001) in Denmark being the most famous.

Human burials in ships may be inhumations as well as cremations. The burial customs relating to ship cremations vary widely. For example, one form of cremation known from Viking period Birka was the scattering of cremation deposits with pyre remains at the burial place. This type of

"Corresponding author. E-mail: rallmae@gmail.com cremation burial sometimes contained ship rivets, indicating that a ship was probably burned together with human remains (Pulsiano, Wolf 1993, 238). The same kind of archaeological finds are known from Estonia. Remains with numerous ship rivets have been found in the graves of Lagedi XIII, Aseri I, and Rae I (Jaanits et al. 1982, 270; Lang 2007, 192). With the Lagedi grave there is also the possibility that a ship with human remains was cremated at the burial place (Lang 2007, 192). The remains of ships, cremated bones and goods were mainly carried from the pyre to the burial place, although the actual burial practice related to cremation is not archaeologically accessible (Müller-Wille 1974, 192-193, 197). Recently the Viking period harbour in Viltina, Saaremaa Island was discovered. The cultural layer there contained many ship rivets, iron nails and other pieces of iron. Unburnt and cremated bones were also recovered (Mägi 2007, 124-125).

Ship graves with inhumations during the Vendel Era (550-800 AD) are largely found in southern and central Sweden. The famous ship grave at Sutton Hoo (Suffolk, England) is also from this period (Evans 1986; Carver 1992). Human cremation in ships was prevalent in Sweden during the Viking period; approximately 10 burial places with ship inhumations of the Viking period are known from central and eastern Sweden (Müller-Wille 1974; Rundkvist, Williams 


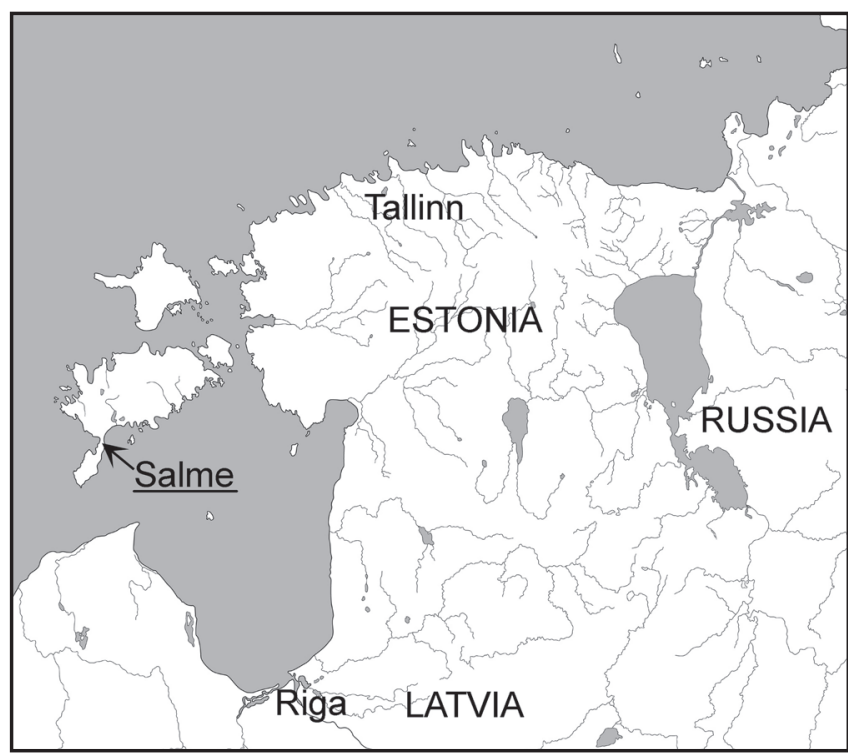

Figure 1. Location of Salme village.

2008, 89). In Finland ship graves are commonly linked to cremation during the Vendel and Viking periods, although the only known ship grave with an inhumation is from Karrböle 8 , on the Aland Isles, dating from the $9^{\text {th }}$ to $11^{\text {th }}$ centuries (Anderson 1963; Müller-Wille 1974, 199; Westerdahl 1985). Ship graves with inhumations were not previously evident in Estonia or other Baltic states, making the Salme I ship the first find of its kind (Konsa 2008; Konsa et al. 2009). In summer 2010, 30 metres from the Salme I ship grave another ship burial with inhumations was exposed (Peets et al. 2011). The archaeological investigation of the Salme II ship grave continued through the summer of 2011, therefore it is not comprehensively discussed in this paper.

\section{Outline of material and methods}

In autumn 2008 human skeletons came to light during cabling work in the village of Salme, on Saaremaa Island, Estonia (Figure 1). Construction work was suspended and archaeological rescue excavations initiated. Unfortunately most of the human bones were already removed. After a week of archaeological excavations the contour of an ancient ship was discovered and it became evident that an important discovery for Estonian archaeology had been made - an ancient ship with inhumations.

The human osteological material from the Salme ship was commingled and fragmentary, and unfortunately the exact location of human bones was not recorded on site. However, numerous photographs were taken during excavation and some bone assemblages were packed exactly as they were recovered.

The bones were analysed using the method of recurrent bone fragments. The sex of skeletons was determined according to widely used osteological standards (Miles 1963; WEA 1980; Ubelaker 1978; Brothwell 1981; Buikstra, Ubelaker 1994; Bass 2005; Mays 2006).

Age was determined on the basis of tooth wear as the bestpreserved diagnostic parts of the skeletons were the maxillae and mandibles. Three different methods (Miles 1963; Gerassimov in Aleksejev and Debets 1964; Brothwell 1981) were used for age determination and the most recurrent age range was considered the most probable. For estimating the severity of deposits of dental calculus and alveolar resorption the scale proposed by Brothwell (1981) was used. For stature reconstruction two methods were used: Trotter, Gleser (1952) and Gerhards (2000). The placement and plausible positions of bodies inside the ship contour were determined on the basis of photos taken during archaeological work taking into account the information derived from those bone

Table 1. ${ }^{14} \mathrm{C}$ datings of bone material from Salme I ship.

\begin{tabular}{|c|c|c|c|c|c|}
\hline \multirow[t]{2}{*}{ Lab. No. } & \multirow[t]{2}{*}{ Material } & \multicolumn{3}{|c|}{${ }^{14} \mathrm{C}$} & \multirow[t]{2}{*}{$\delta^{13} \mathbf{C}$} \\
\hline & & Radiocarbon Age & $68.2 \%$ & $95.4 \%$ & \\
\hline Hela-1914 & Human skull & $1285 \pm 30 \mathrm{BP}$ & $\begin{array}{l}670 \mathrm{AD}(41.4 \%) 720 \mathrm{AD} \\
740 \mathrm{AD}(26.8 \%) 770 \mathrm{AD}\end{array}$ & 660AD-780AD & -20.8 \\
\hline Hela-1915 & Human skull & $1320 \pm 30 \mathrm{BP}$ & $\begin{array}{l}\text { 650AD (51.8\%) 710AD } \\
740 \mathrm{AD}(16.4 \%) 770 \mathrm{AD}\end{array}$ & 650AD-780AD & -20.2 \\
\hline Hela-1916 & Bovine tibia & $1310 \pm 30 \mathrm{BP}$ & $\begin{array}{l}\text { 660AD }(49.3 \%) 710 \mathrm{AD} \\
740 \mathrm{AD}(18.9 \%) 770 \mathrm{AD}\end{array}$ & 650AD-780AD & -20.9 \\
\hline Hela-2169 & Bovine femur head & $1154 \pm 30 \mathrm{BP}$ & $\begin{array}{l}\text { 780AD (1.9\%) } 790 \mathrm{AD} \\
\text { 810AD }(10.8 \%) \text { 850AD } \\
\text { 860AD }(26.8 \%) \text { 900AD } \\
\text { 910AD }(28.7 \%) \text { 970AD }\end{array}$ & 770AD-980AD & -21.4 \\
\hline Hela-2495 & Bovine femur head & $1287 \pm 30 \mathrm{BP}$ & $\begin{array}{l}675 \mathrm{AD}(42.0 \%) 718 \mathrm{AD} \\
743 \mathrm{AD}(26.2 \%) 769 \mathrm{AD}\end{array}$ & 663AD-776AD & -21.9 \\
\hline Hela-2170 & Whalebone & $1671 \pm 30 \mathrm{BP}$ & 590AD $(68.2 \%) 700 \mathrm{AD}$ & 530AD-780AD & -16.1 \\
\hline Hela-2171 & Whalebone & $1607 \pm 30 \mathrm{BP}$ & $650 \mathrm{AD}(68.2 \%) 770 \mathrm{AD}$ & 590AD-840AD & -16.2 \\
\hline
\end{tabular}

Atmospheric data from Reimer et al. (2004); OxCal v3.10 Bronk Ramsey (2005); cub r:5 sd:12 prob usp [chron]. 
assemblages packed as one unit. Comparing the photos of skeletons with those bones collected as one unit, some conclusions about the placement and positions of the bodies in the ship were possible.

The finds from the Salme ship included nearly 700 separate animal bones, which, despite the sandy and gravelly soil were very well preserved. Animal bones came to light within the preserved ship contour as well as in that part destroyed by cabling and road construction. Since animal bones were not found outside the ship contour, nor from the profiles of ditches dug further from the ship, we may assume that the recovered bones were originally all located inside the ship. To determine the age at death of the animals, researchers examined for the ages of the ossification of epiphyses (Silver 1969) and the replacement of milk teeth and eruption of permanent teeth (Schmid 1972). Sheep and goat bones were identified on the basis of distinctive identifiers (Boessneck, Müller, Teichert 1964).

Absolute dates on the bone material were obtained by AMS radiocarbon dating at the Finnish Museum of Natural History, Helsinki University (Hela-1914, Hela-1915, Hela1916, Hela-2169, Hela-2495, Hela-2170, Hela-2171).

\section{Results of analyses}

\subsection{Radiocarbon dates}

As the archaeological complex was repeatedly disturbed it was necessary to estimate whether the ship, artefacts and osteological material constituted one unit and dated from the same time period. The fragments of two human craniums (S1 and S4) were dated by AMS radiocarbon dating (Hela-1914 and Hela-1915). One animal bone date was obtained from a calf tibia (Hela-1916). Radiocarbon dating (Table 1) of osteological materials confirmed that the burials were from the same complex and from the same time period. Dated wood from the ship also indicated that the disturbed archaeological complex was one unit from the second half of the $7^{\text {th }}$ century or the beginning of $8^{\text {th }}$ century (Konsa et al. 2009). Gaming pieces made of whale and cattle bone (Table 1) found in the ship grave dated (Hela-2169, 2170, 2171) to approximately the same period (Peets, Maldre 2010).

\subsection{Analyses of human bones}

Once construction work was stopped, preliminary analysis of recovered human bones was conducted on site. The analysis indicated the presence of at least five individuals with laboratory analyses increasing that number to seven.

The excavation area was divided into three parts: the cable trench area (a disturbed area from which most commingled human bones were gathered); the edge of the cable trench, where presumably intact upper bodies and craniums were found; and the area around the single stone found within the ship's contour, where commingled bones and some articulated bones were also found (Figure 2).

Initially the mandibles and maxillae were paired. The loose teeth were put in the correct positions and matching pairs of upper and lower jaw were identified by the congruity of

Figure 2. Location of bones in Salme boat.

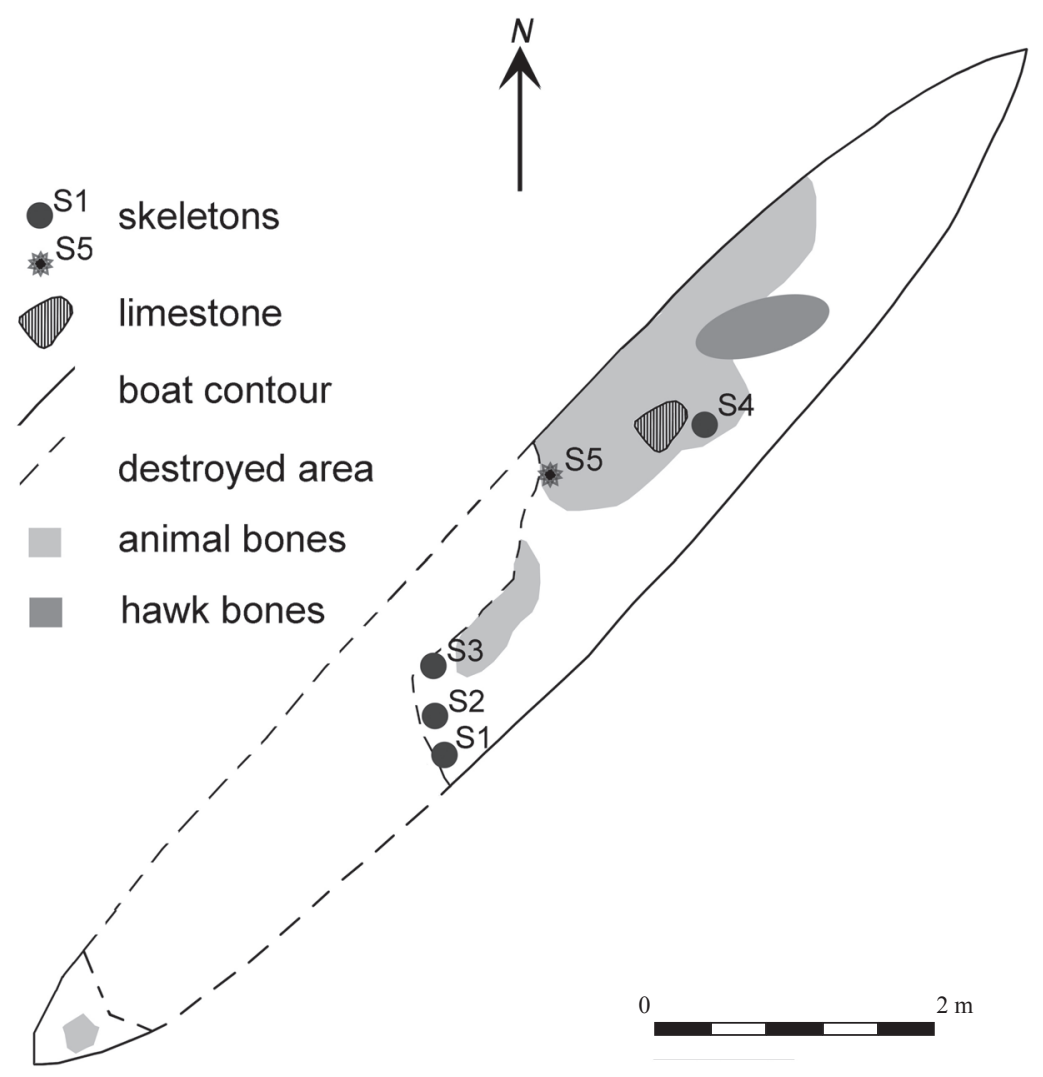


occlusal surfaces of upper and lower teeth. It became evident that there were well-preserved jaws for seven individuals (except for one cranium, the mandible of which is lost). Four jaws were related to craniums and three not. The latter were discovered among the commingled bones of the disturbed area of the ship (Table 2). All craniums were fragmented, particularly those in upper layers of the soil. Following the matching of the jaws, the innominate bones were paired. It was possible to pair fragments of 6 innominate bones, and to determine 7 left ones (Table 2). Finally, foot bones and distal parts of tibiae were analysed, and at least seven individuals confirmed (Table 2). Other post-cranial fragments were less recurrent than those noted above, due to the overall poor preservation of bone material.

Determination of sex accounted for all possible descriptive diagnostic traits on cranial and post-cranial skeletal material. It was concluded that all 7 skeletons were male. Age was determined on the basis of tooth wear. Three different methods were used and the most recurrent age range was accepted as the most plausible (Table 3).

Dental and alveolar pathologies were recorded and are presented in Table 4. It is noteworthy that only one case of dental caries was found. Regardless of age the periodontal abscess (Table 4), alveolar resorption (periodontal disease),

Table 2. Analyses of commingled bones - minimum number of individuals.

\begin{tabular}{|c|c|c|c|c|c|c|c|c|}
\hline \multirow{2}{*}{$\begin{array}{l}\text { Diagnostic parts of skeletons } \\
\text { Cranial part of skeleton }\end{array}$} & \multicolumn{2}{|c|}{$\begin{array}{l}\text { Number of } \\
\text { individuals }\end{array}$} & \multicolumn{2}{|c|}{$\begin{array}{c}\text { Cable trench } \\
\text { area }\end{array}$} & \multicolumn{2}{|c|}{ Around the limestone } & \multicolumn{2}{|c|}{$\begin{array}{l}\text { On the edge of } \\
\text { the cable ditch }\end{array}$} \\
\hline & & & & & & & & \\
\hline Maxilla and mandible (pair) related to craniums & \multicolumn{2}{|c|}{4} & \multicolumn{2}{|c|}{-} & \multicolumn{2}{|c|}{1 (the mandible is absent) } & \multicolumn{2}{|c|}{3} \\
\hline Maxilla and mandible (pair) without related cranium & \multicolumn{2}{|c|}{3} & \multicolumn{2}{|c|}{3} & \multicolumn{2}{|c|}{-} & \multicolumn{2}{|c|}{-} \\
\hline \multicolumn{9}{|l|}{ Post-cranial skeleton } \\
\hline Side & Left & Right & Left & Right & Left & Right & Left & Right \\
\hline Innominate (fragments) & 7 & 6 & 6 & 5 & 1 & 1 & - & - \\
\hline Calcaneus & 7 & 5 & 5 & 4 & 2 & 1 & - & - \\
\hline Talus & 4 & 7 & 2 & 6 & 2 & 1 & - & - \\
\hline Distal end of tibial bone & 7 & 6 & 6 & 5 & 1 & 1 & - & - \\
\hline
\end{tabular}

Table 3. The results of age and sex determination.

\begin{tabular}{llcccc}
\hline Skeletons & Sex & \multicolumn{3}{c}{ Dental age in years } & $\begin{array}{c}\text { Most recurrent } \\
\text { age range }\end{array}$ \\
\cline { 3 - 5 } & & Brothwell 1981 & Gerassimov 1964 & Miles 1963 & \\
\hline S1 & Male & $25-35$ & $30-35$ & $25-35$ & $30-35$ \\
S2 & Male & $17-25$ & $18-25$ & $18-24$ & $18-25$ \\
S3 & Male & $20-30$ & $25-35$ & $25-30$ & $25-30$ \\
S4* & Male & $20-30$ & $20-30$ & $18-24$ & $20-25$ \\
S5 & Male & $25-30$ & $25-30$ & $18-24$ & $25-30$ \\
S6 & Male & $35-45$ & $35-40$ & $36-38$ & $35-40$ \\
S7 & Male & $40-45$ & $40-50$ & $42-46$ & $40-45$ \\
\hline
\end{tabular}

* - mandible absent.

Table 4. Dental and alveolar pathologies (stages after Brothwell 1981).

\begin{tabular}{|c|c|c|c|c|}
\hline Skeleton age & Dental calculus & Dental caries & Periodontal abscess & Alveolar resorption \\
\hline S1 30-35 & 1 & - & $\begin{array}{c}\text { Left } \mathrm{M}^{1} / \mathrm{M}^{2} \\
\text { Left } \mathrm{M}_{1} / \mathrm{M}_{2} \\
\mathrm{I}^{1} / \mathrm{I}^{2}\end{array}$ & 1 \\
\hline S2 18-25 & 1 & Right $\mathrm{M}_{1}$ & Left $\mathrm{M}_{2}$ & 2 \\
\hline S3 25-30 & 1 & - & - & 2 \\
\hline $\mathrm{S} 4 * 20-25$ & 1 & - & - & 1 \\
\hline S5 25-30 & 0 & - & - & 1 \\
\hline S6 35-40 & 1 & - & $\begin{array}{c}\text { Left } \mathrm{M}^{2} \\
\text { Right } \mathrm{M}^{2}\end{array}$ & 2 \\
\hline S7 40-45 & 1 & - & Right $\mathrm{M}^{1} / \mathrm{M}^{2}$ & 2 \\
\hline
\end{tabular}


Table 5. The reconstructed body height of men in Salme I ship (cm).

\begin{tabular}{lcc}
\hline \multicolumn{1}{c}{ Method bone } & Gerhards (2000) & Trotter \& Gleser (1952) \\
\hline Humerus S1 & 179,7 & 182,9 \\
Humerus S2 & 175,5 & 176,7 \\
Humerus S3 & 178,5 & 181,3 \\
Tibia commingled bones & 174,6 & 177,1 \\
Femur (pair) commingled bones & 178,3 & 180,6 \\
& 178,3 & 180,6 \\
\hline
\end{tabular}

Table 6. The number of determinable cattle bones.

\begin{tabular}{clcccc}
\hline \multirow{2}{*}{ Age in months } & \multicolumn{1}{c}{ Bone } & \multicolumn{4}{c}{ Epiphysis } \\
\cline { 3 - 5 } & & Juv. & Open & In fusion & Fused \\
\hline \multirow{2}{*}{$7-10$} & Tub. supraglenoidale & 2 & 1 & - & 2 \\
\hline \multirow{2}{*}{$12-18$} & Humerus dist. & 2 & 1 & - & 1 \\
& Radius prox. & 1 & - & - & - \\
\hline $24-30$ & Tibia dist. & 2 & 1 & - & - \\
\hline $36-42$ & Tuberositas calcanei & 2 & 2 & - & 2 \\
\hline 42 & Femur prox. & 2 & 1 & - & - \\
\hline \multirow{2}{*}{$42-48$} & Humerus prox. & 2 & - & - & 1 \\
& Ulna prox. & $1(2 ?)$ & $1 ?$ & - & 1 \\
& Ulna dist. & 1 & - & - & - \\
& Radius dist. & 1 & 1 & - & - \\
& Femur dist. & 2 & 1 & - & 1 \\
& Tibia prox. & 2 & - & - & 1 \\
\hline
\end{tabular}

and new bone formation in alveolar sockets was quite common within the group. These pathologies may indicate periodontal disease, for example, possibly caused by scurvy. Scurvy was quite common in prehistoric times, but quite difficult to diagnose in its early stages on the basis of skeletal materials. Skeletally the evidence for scurvy consists of new bone formation, potentially anywhere on the skeleton
(Roberts, Manchester 1995). In its early stages scurvy may affect the gums causing swelling and bleeding and being infectious (Maat 2004).

Stature was calculated using reconstruction models compiled by Gerhards (2000) and Trotter and Gleser (1952). It became evident that the men had been quite tall (Table 5), especially S1 and S3, in the context of Saaremaa men
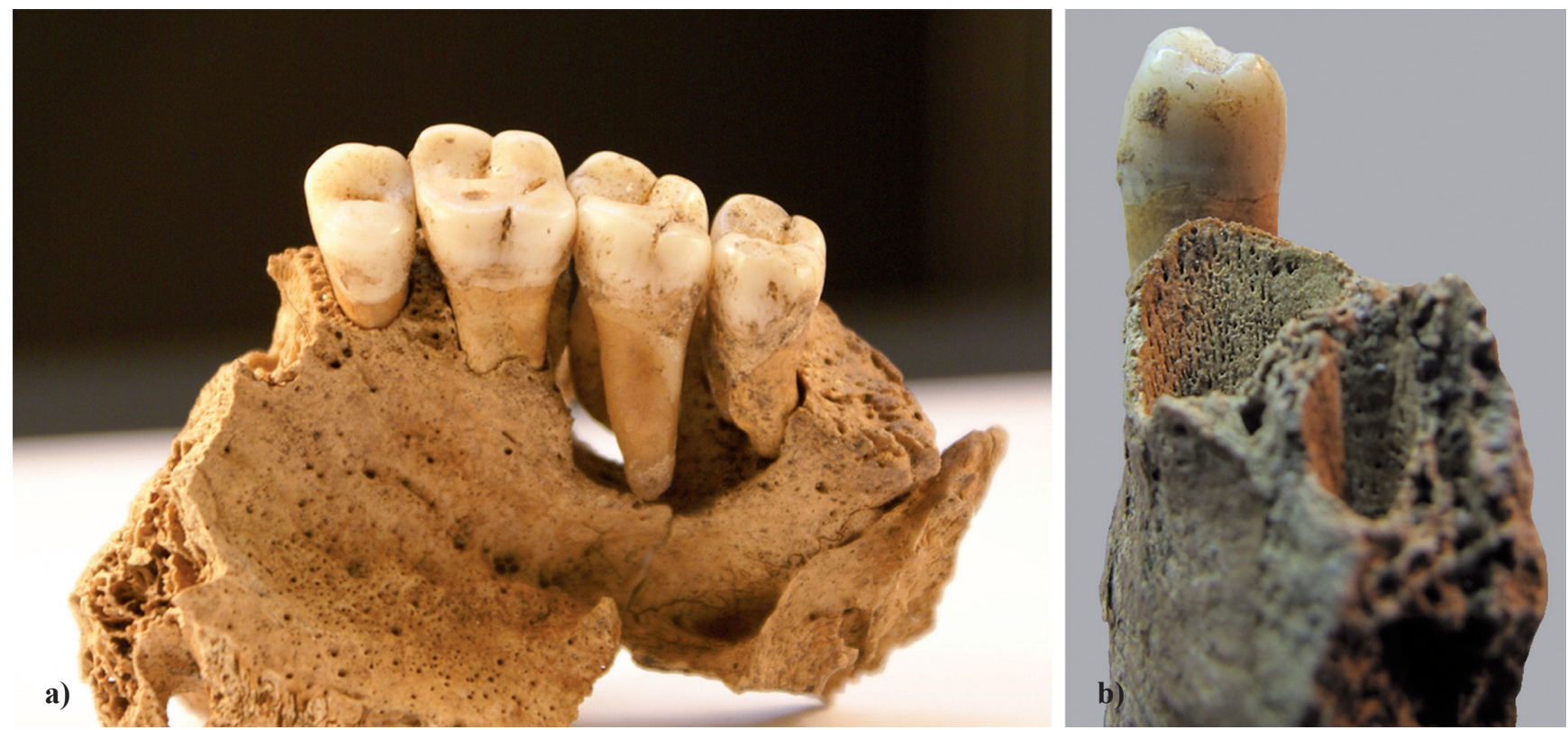

Figure 3. Pathological changes on human jaws: a) periodontal abscess; b) new bone formation in tooth socket. (Photo by Raili Allmäe). 


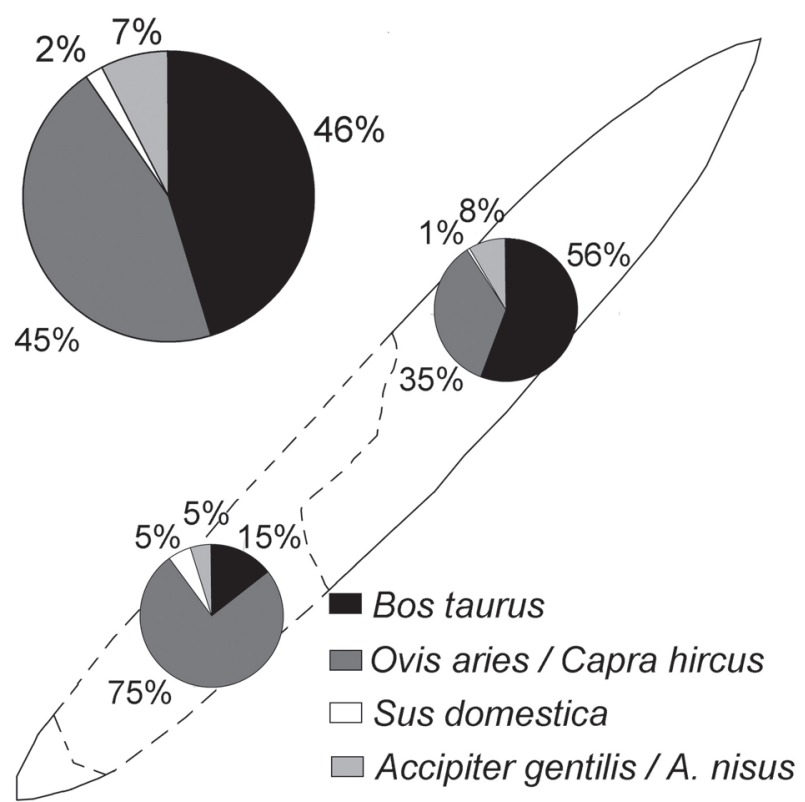

Figure 4. Composition of species“ in different parts of boat. Boat contour from Konsa et al (2009), adapted.

throughout the millennium. A mean stature over $175 \mathrm{~cm}$ for males has been common on Saaremaa since the second half of the $20^{\text {th }}$ century, but not earlier (Heapost, Thetloff 1999 ; Heapost 2002, 2003). Unfortunately there is no data on male stature from the second half of first millennium on Saaremaa, and also not much information about the stature of Middle and Late Iron Age men in Estonia. There are reconstructions of stature based on two male skeletons from the second Maidla stone grave of the $5^{\text {th }}$ to $7^{\text {th }}$ centuries AD (Middle Iron Age) in Läänemaa. Both were quite tall according to the Trotter and Gleser formula (1952), the first being 172-176 cm and the second 175-178 cm (Allmäe 2003).

\subsection{Analyses of mammal bones}

Animals from the site include cattle (Bos taurus), sheep (Ovis aries), goat (Capra hircus) and pig (Sus domestica). The number of bone fragments of cattle and sheep/goat is more or less equal, while hawk bones constitute about 7\% of all identifiable bones. Only a few bone fragments belong to pigs. Within the preserved part of the ship contour cattle bones prevail while sheep/goat bones were more numerous among the bones the exact discovery location of which could not be established and which mainly came from the part of the site destroyed by the ditch (Figure 4).

There were 328 cattle bones identified, from at least six individuals: two calves, one heifer (younger than 7-10 months), one heifer or young animal (younger than 3 years) and two adult animals (over 3-3.5 years) (Table 6). On some calf spondyls, the ossification border between the body and arch still slightly visible, indicating that the animal was probably slaughtered during the first month. There are 326 sheep or goat bones from at least ten individuals (Table 7). Spondyls belonging to at least two lambs have bodies and arches only partly coalescent, so their slaughter age was probably between 3 to 6 months. Kid skull and mandibles evidently belong to an individual younger than 6 months, as indicated by the erupting $\mathrm{M}_{1}$-s. The number of sheep and goats cannot be determined, as their bones are generally very similar, and the identification further complicated by the fact that most of the bones belonged to young animals. Aside from the above noted kid skull, there may be remains of a goat of about 10 months although most bones appear to belong to sheep.

There were 15 fragments of pig bones from at least two individuals, one younger and the other older than 3.5 years. There were no piglet bones.

Anatomically the absence of bones from the distal parts of limbs strikes the eye (Figure 7). Examples of the proximal row of carpal and tarsal bones are found, but no a single bone or fragment from the distal lines could be identified. Cranial

Table 7. The number of sheep/goat bones.

\begin{tabular}{clcccc}
\hline \multirow{2}{*}{ Age in months } & \multicolumn{1}{c}{ Bone } & \multicolumn{3}{c}{ Epiphysis } \\
\cline { 3 - 5 } & & Juv. & Open & In fusion & Fused \\
\hline \multirow{2}{*}{$6-8$} & Tub. supraglenoidale & - & $2(3 ?)$ & - & 2 \\
\hline $6-10$ & Acetabulum pubis & - & 4 & 1 & 1 \\
\hline \multirow{2}{*}{10} & Humerus dist. & - & - & 3 & 4 \\
& Radius prox. & - & - & 3 & 5 \\
\hline \multirow{2}{*}{$30-36$} & Tibia dist. & - & 5 & - & 1 \\
\hline \multirow{2}{*}{36} & Femur prox & - & 7 & - & 1 \\
& Tuberositas calcanei & - & 3 & - & 1 \\
\hline \multirow{2}{*}{$36-42$} & Humerus prox. & - & 4 & - & 2 \\
& Radius dist. & - & 4 & - & 1 \\
& Ulna prox. & - & 3 & - & 2 \\
& Femur dist. & - & 8 & - & 1 \\
& Tibia prox. & - & 6 & - & 1 \\
\hline
\end{tabular}


bones are also nearly completely missing, except for the skull fragments, mandibles and teeth of a kid, and the canine of a sow recovered from the part of the site damaged by the ditch. The disproportionally large number of vertebral fragments is mainly due to the numerous loose epiphyses. Hence most of the mammal bones come from the fleshy trunk parts, what suggests that the animals were in the ship as butchered meat rather than as whole carcasses. Rather surprisingly there are no skull fragments, metacarpal and metatarsal bones or phalanges of pigs, despite the fact that pig's head and legs were commonly used for food.

\subsection{Analyses of bird bones}

A total of 47 bird bones (including 12 broken or damaged fragments) were identified. 48 small bone fragments and 4 shafts were not identifiable because of pathological changes. The state of preservation of all bones was nearly the same, and they were of a similar colour, and very fragile. They have been heavily damaged by root etching and probably also by humus acids. Plant roots have also been preserved inside the shafts. The bones probably belong to two birds: a female goshawk (Accipiter gentilis) and a female sparrowhawk (Accipiter nisus). Both individuals have pathological changes. The goshawk has some bone growth at the distal end of the left femur and deformation of the proximal side of the left tibiotarsus (Figure 5), probably due to a healed fracture. Since the changes were in the area of the femur/tibiotarsus joint and had formed during the lifetime of the bird, the use of the bird in falconry cannot be ruled out. The sparrowhawk had a small deformation on the left ulna shaft - which could be the result of changes inside the bone - some bone growth in the joint of the coracoid (fovea

Figure 6. Pathological changes on the bones of sparrowhawk: a - some bone growth in the joint part of coracoid and left humerus; $\mathrm{b}$ - one growth on fragments of long bones . (Photo by Liina Maldre).

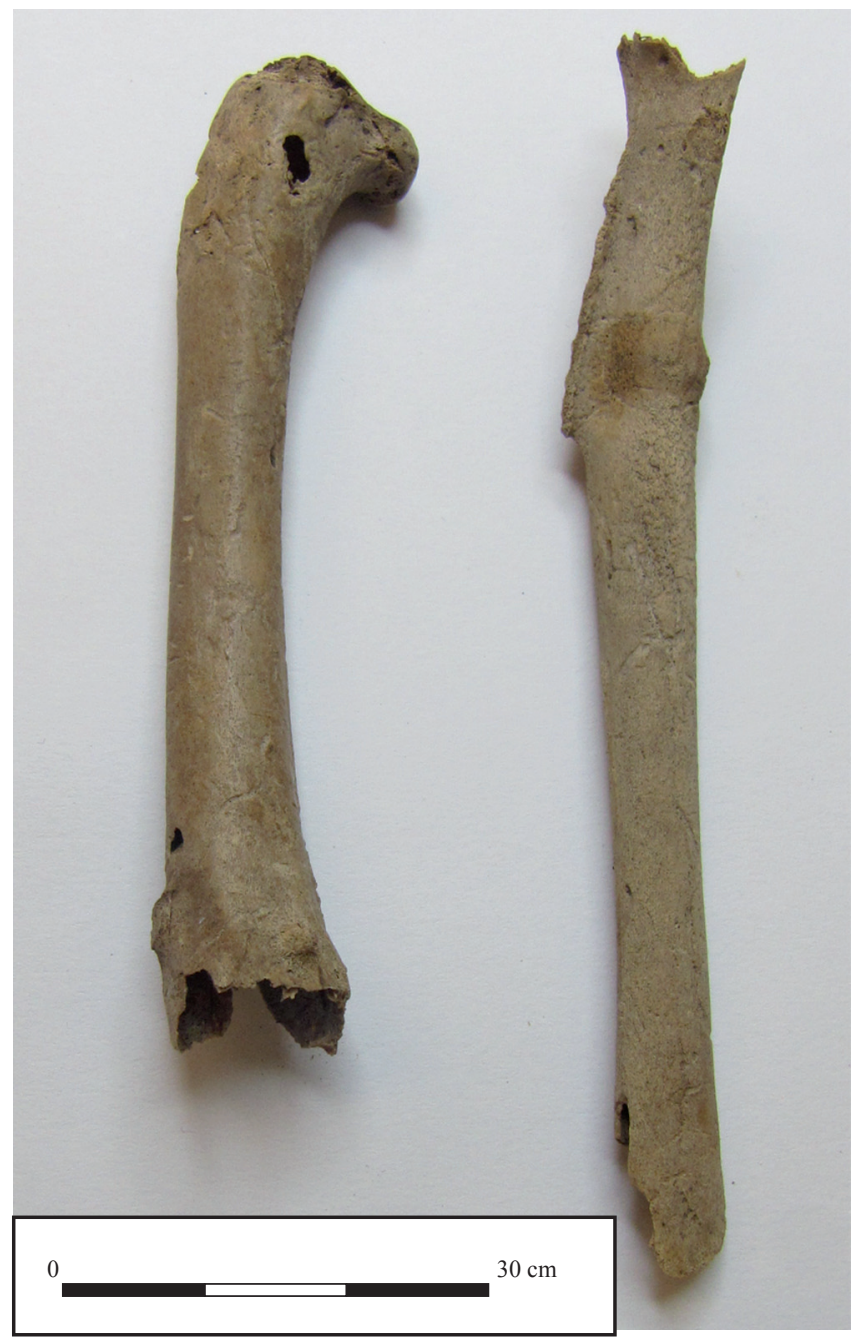

Figure 5. Pathological changes on left femur and tibiotarsus of goshawk. (Photo by Liina Maldre).

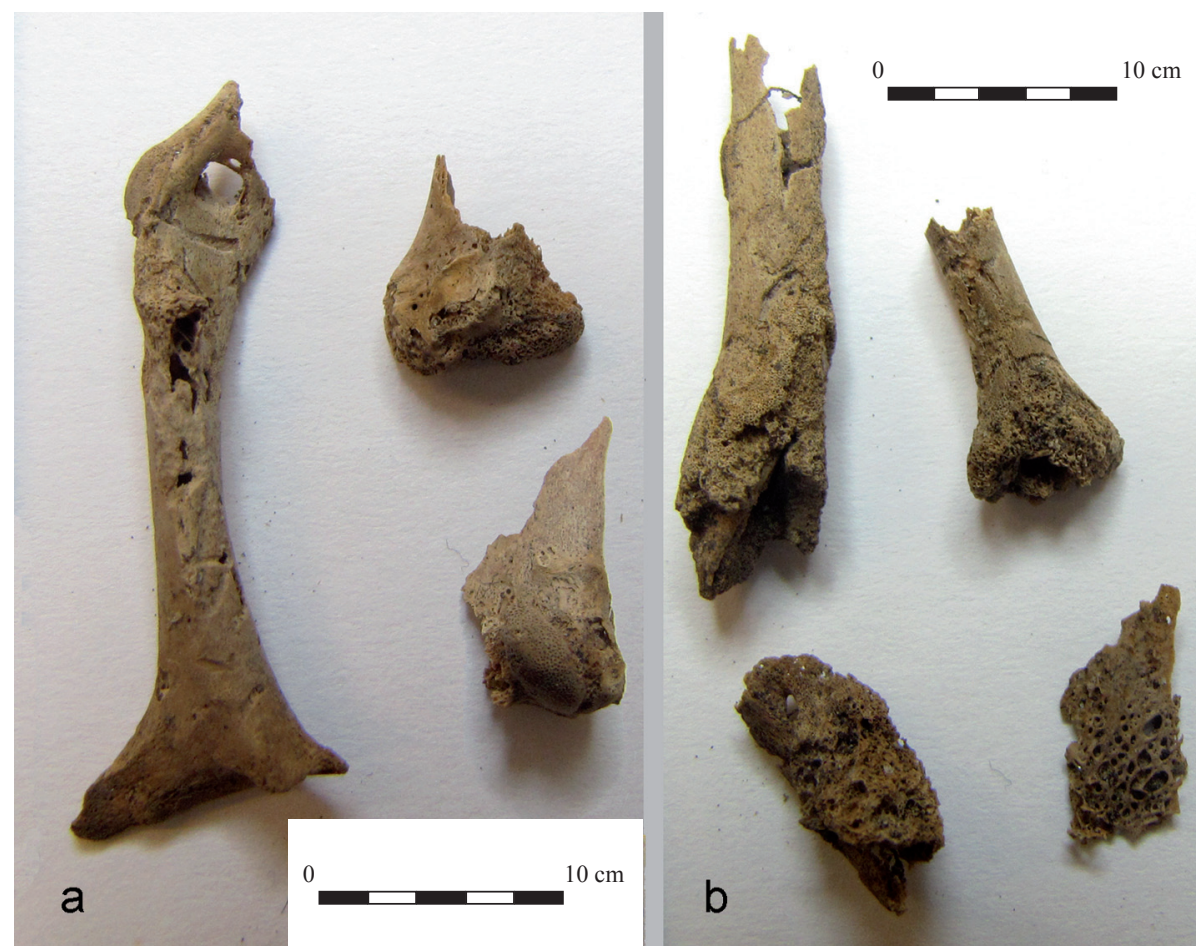




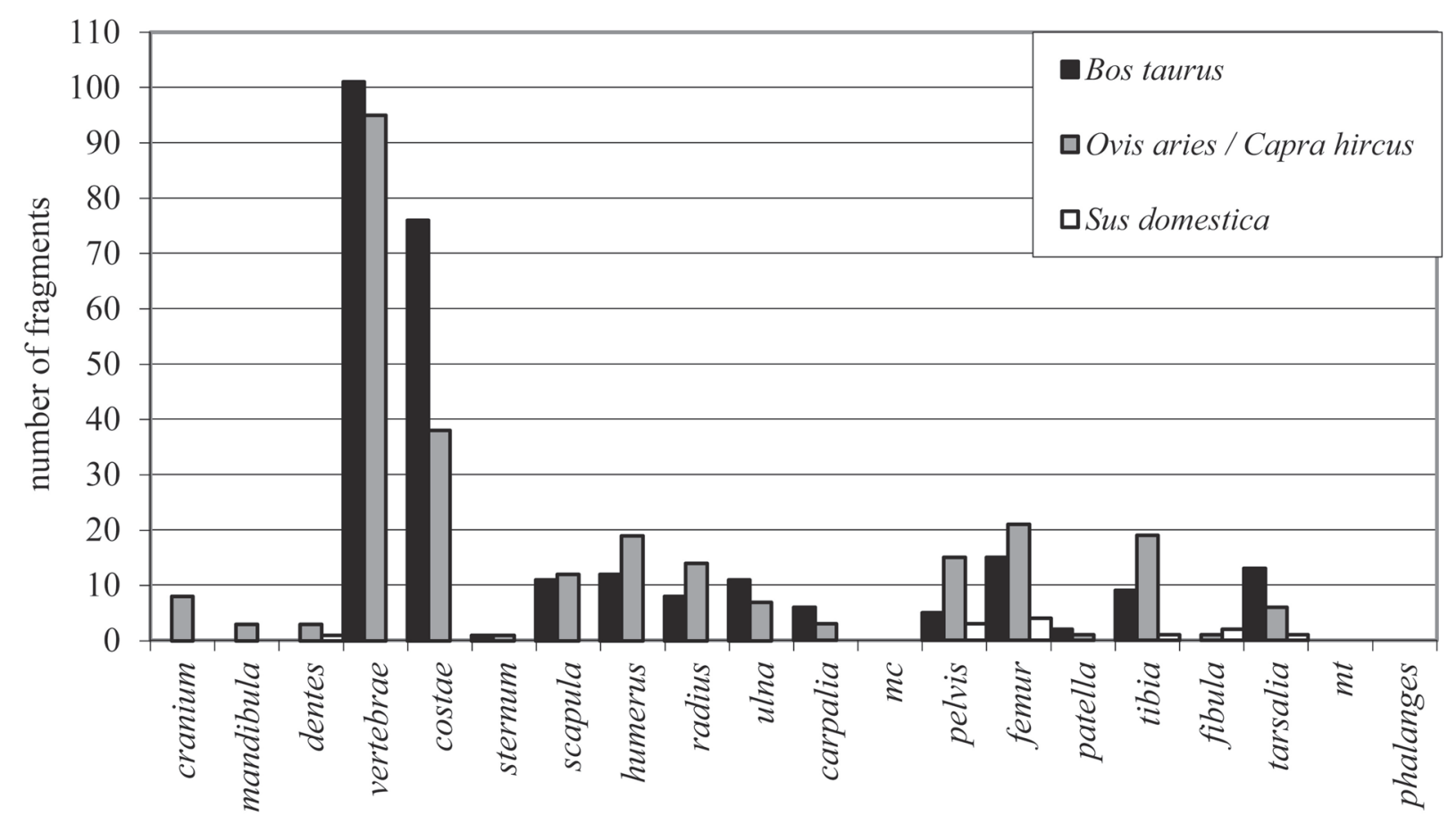

Figure 7. Anatomical composition of archaeozoological material.

coracohumeralis), and similar growth on the left humerus (Figure 6a) Very similar structures can be observed on 4 unidentifiable fragments (Figure 6b). It is therefore possible that these fragments belong to the "missing" bones of the sparrowhawk.

16 goshawk bones were found, including bones of legs and the upper limb (humerus, ulna and coracoid). A sparrowhawk was found with nearly all axial bones and limbs. Cervical vertebra and skull bones were missing. This suggests that these birds were 'buried' without the head. Unidentifiable bone fragments ( 48 pieces) belong to birds of approximately the same size as the preserved sparrowhawk bones are probably part of the sparrowhawk's skeleton.

\subsection{The placement and position of human bones in the ship}

The prow of the ship points to the north east (Konsa et al. 2009) with the human remains located mainly amidships and aft (Figure 2). The placement of these remains within the ship and their anatomical positions were not documented on site, and the reconstruction of body positions is based on photographs taken during excavation, which exposed three crania with upper body skeletal remains in anatomical position (Figure 8) on the edge of the cable trench.

Skeleton $\mathrm{S} 1$ is a $30-35$ year old male facing the stern. The body leans backwards, the head has fallen towards the chest and the shoulders are up in a relaxed position. The body has slumped to left, as from a sitting position. On the right front side of the cranium is a burn mark, possibly caused by modern activities, perhaps during construction work or welding on site. The skeleton was not deep and the heat of welding may have charred the bone surface. Skeleton S2 is an 18-25 year old male facing the bow. The body is lying on the right side and leaning on S1's right shoulder and chest, as though fallen asleep or exhausted (Figure 8). Skeleton S3 is a 25-30 year old male facing the bow (Figure 8), prone, head leaning on the right cheek. The upper extremities are stretched out from the body. Unfortunately the lower parts of skeletons S1, S2 and S3 were destroyed and the directions of the spinal columns and the positions of lower extremities were not observable. This information could have been crucial to understanding the initial positions of the bodies, especially in determining the sitting position of the corpses.

Skeleton S4 - this position of this male, aged 18-25, is more dubious. In the middle of ship, next to the stone, a cranium without mandible was found. The cranium has been partly destroyed and was probably relocated during some earlier construction work. In addition, the left innominate bone articulated with the proximal part of the femur was found partly lying on the same limestone. Some fragments of the left fibula and tibia also seem to be in their initial places (Figures 9, 10) and are probably related to S4. No more articulated bones are observable in the photographs. It is noteworthy that one of the gaming pieces was found beside the innominate bone, which could have been in the pocket or in the hand of S4. The S4 body was probably lying more on the left side with bent knees. The positions of the articulated bones and cranium may also indicate burial in 
Figure 8. Skeletons S1, S2 and S3 in situ. (Photos by Külli Rikas and Jürje Koert).
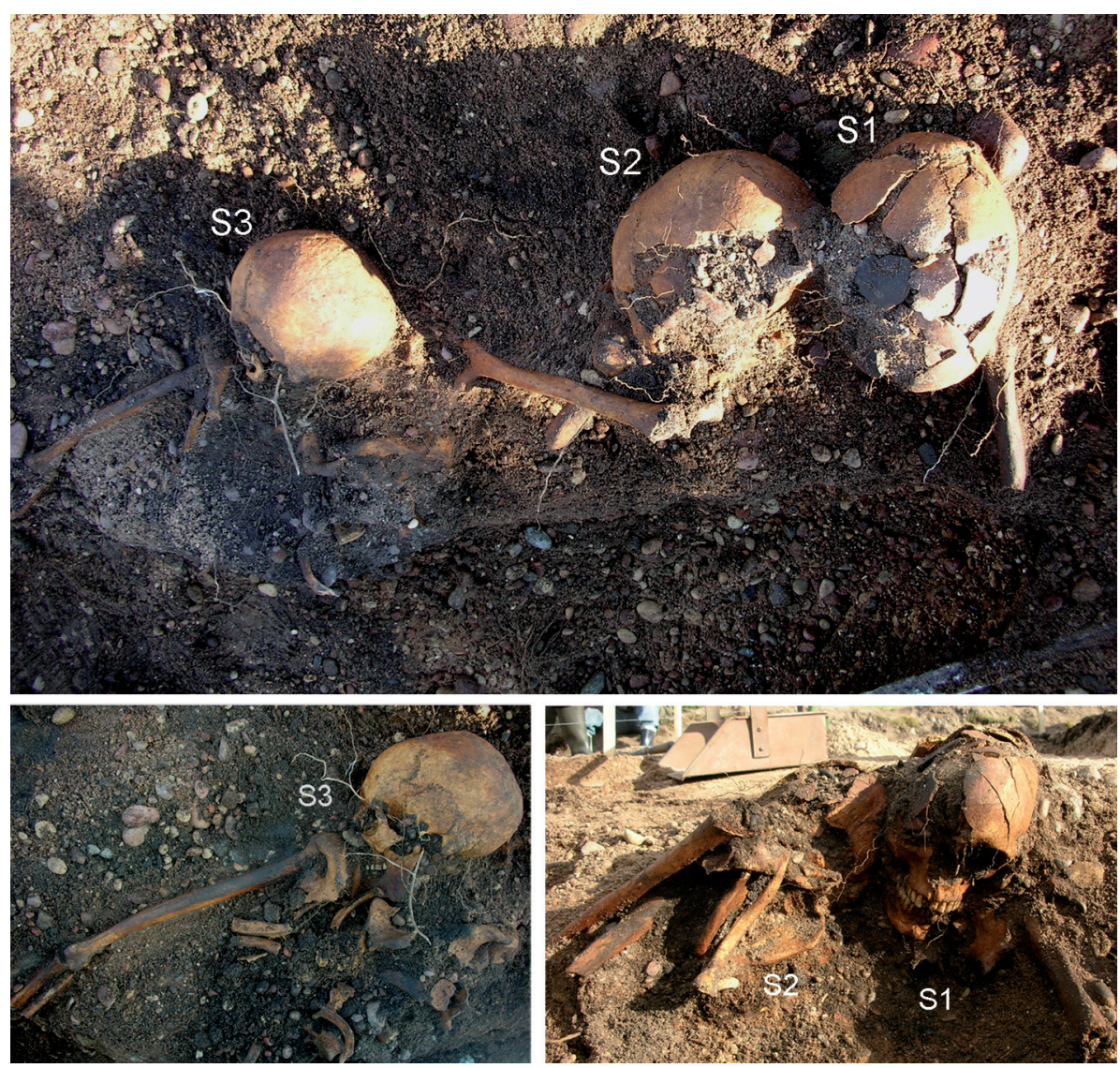

a sitting position. Unfortunately there is no firm evidence to argue that the sitting position of corpses was part of the burial ritual. On the other hand, the skeletons of Tuna in Alsike ship graves VI, XII (Arne 1934) are often found in similar positions - on one side, with flexed knees and for these corpses an initial sitting position has been suggested
(Arne 1934). In the Nabberör ship grave an initial sitting position has also been supposed for two skeletons (Lamm 2002). In the Valsgärde ship grave the deceased have been placed to see the fairway (Arwidsson 1942), while in the Salme ship such deliberate positioning towards one direction cannot be observed.

Figure 9. Skull S4 and the bone assemblage around the limestone in situ. (Photo by Jürje Koert).

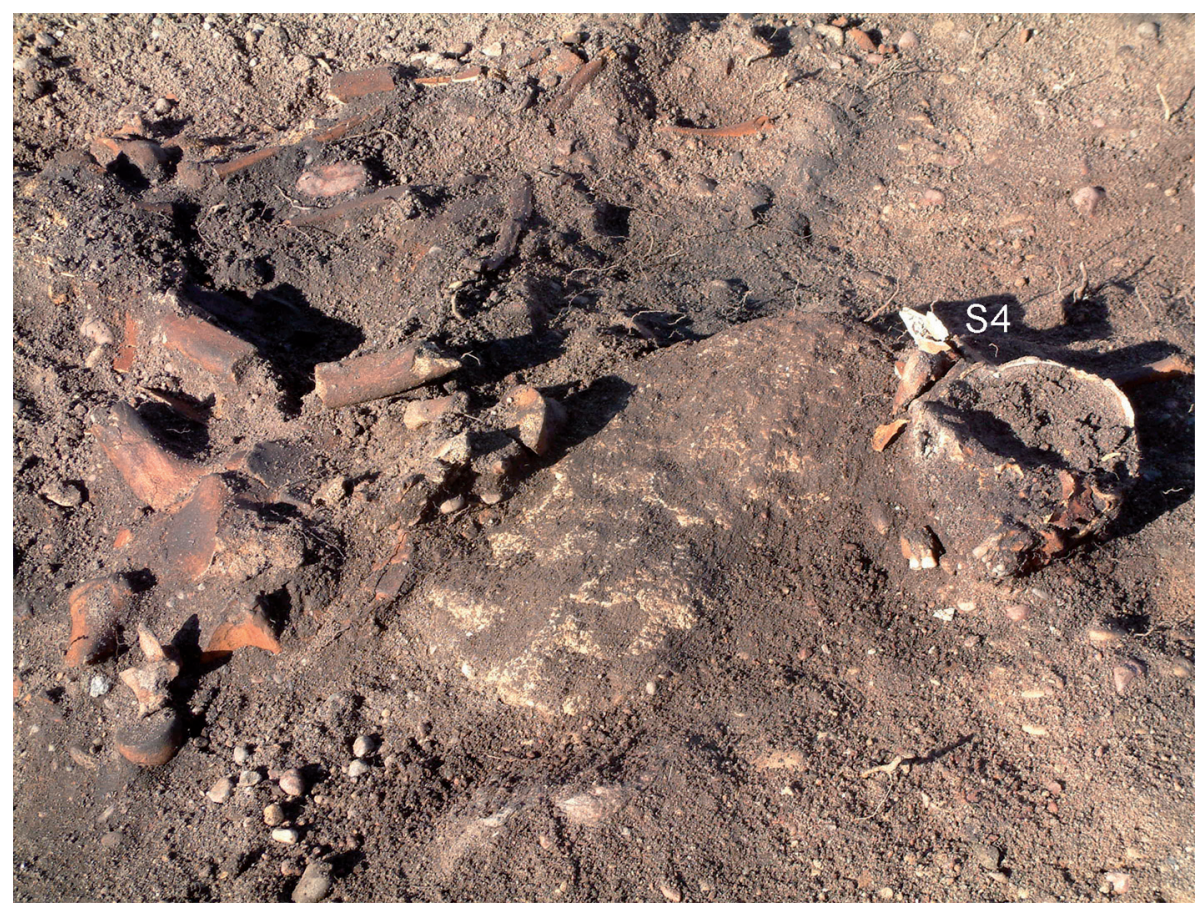




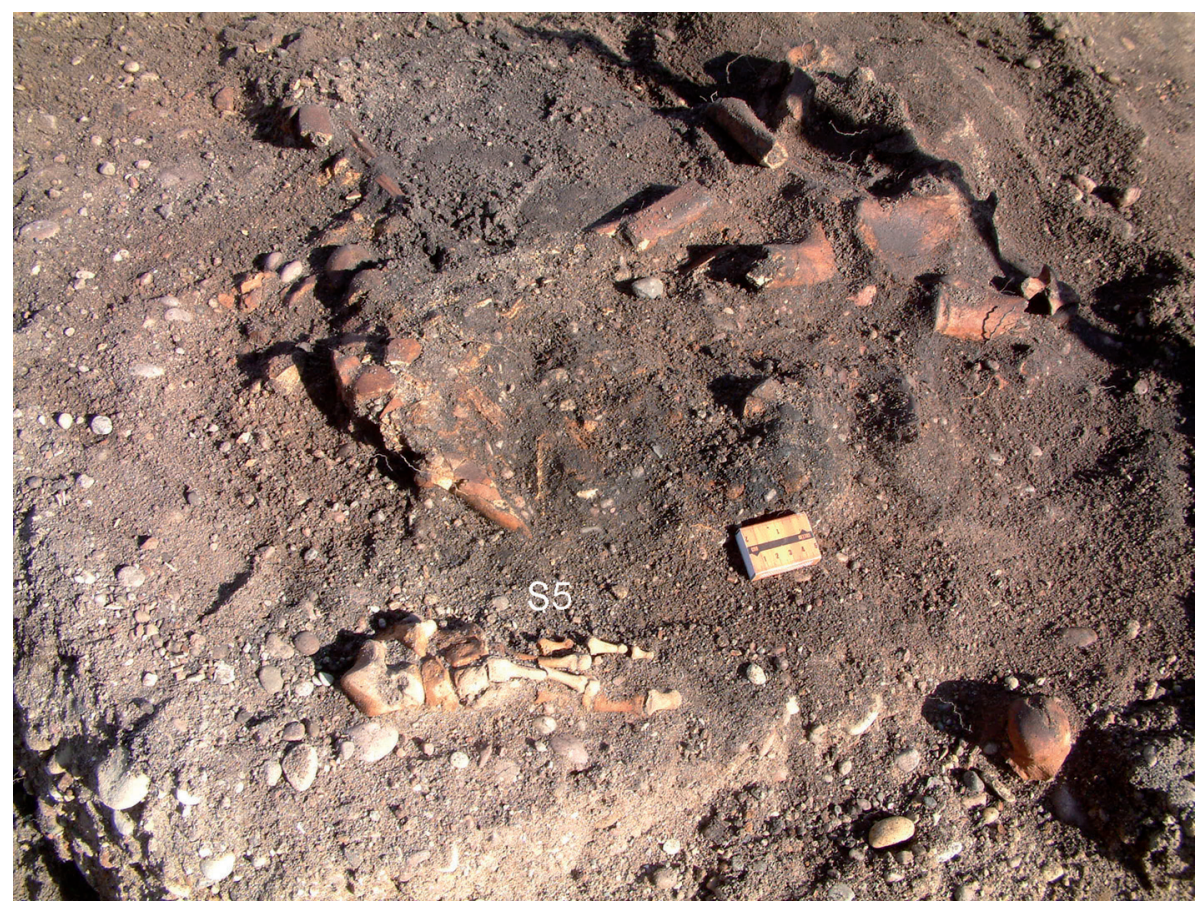

Figure 10. Articulated foot bones of skeleton S5. (Photo by Jürje Koert).

The position of skeleton S5 is totally fictional. The only intact part of skeleton S5 is the articulated bones of the left foot at the edge of the cable trench. The foot was parallel to the ground - like the foot of a sitting, crouching or standing man (Figure 10). The left tibia and fibula should have been vertical to explain such positioning of the foot. The leg could have been in this position for example due to the inner construction of the ship or items stored in the ship, because when a body slumps from a sitting position, or when a corpse is recumbent, a leg cannot remain in such a position unless it is jammed between construction elements or other objects. The intact foot is probably related to the younger adult found mainly within the cable trench. The paired mandible and maxilla of a male aged 25-30 was found in the stern among commingled bones.

The skeletons S6 (male, aged 35-40) and S7 (male, aged 40-45), the oldest of the seven, were also found within the stern or cable trench among commingled bones. It is known that the older and more experienced men were responsible for steering. The placement and hypothetical body positions of the men in the Salme ship are presented in Figure 11.

\subsection{Placement of animal bones in the ship}

Cattle, sheep/goat and pig bones with traces of chopping and cutting confirm that animals where not brought on board as carcasses but as larger or smaller pieces of butchered meat. The heads of the hawks were detached; their skeletons bear no other traces of cutting.

Cattle bones were mainly recovered from around the limestone in the middle of the ship, and forward of the stone (Figure 2), mainly from the larboard side. Except for the heads and distal ends of limbs previously mentioned, all bones are bovine, with fewer bones from young animals. The calcanei of two individuals were identified, as was a tibia fragment from at least one animal and the distal end of the humerus from another. Some vertebrae, humerus, tibia and femur fragments where also found, as were two calcalnei from adult animals.

The remains of sheep and goats were mainly found in the stern although larger and smaller assemblages also came to light amidships and in the bow. A large percentage of these bones were recovered from the area damaged by the cable trench and road construction and hence nothing is known about their location in the ship. Nevertheless we may suppose that most of them come from the stern and were destroyed by the trench. In the port bow fragments of hipbone, femur and tibia belonging to 2 or 3 young individuals were found, together with some fragments of lumbar vertebrae, sternum and ribs. Around the stone, the bones of at least one lamb and one adult sheep were found, mainly front limbs and vertebrae (including one fragment of a cervical vertebra). A large amount of sheep or goat bones were recovered at the edge of the area damaged by the trench. Some fragments of a kid skull and mandible were recovered from the undamaged part of the ship near the trench, and the rest were found among the material collected from the removed soil. These bones probably belong to a single specimen. It is unclear how many bones from this particular kid were found: a large number of sheep or goat bones were recovered from the same area, including lamb/kid vertebrae and limb bones, although discrete skeletons were not discernible.

There are few pig bones in the material. 4 fragments were recovered from the middle of the ship, the remaining 11 from the mixed material, hence there may have been slightly more of them in the stern. Except for a sow's canine, all pig bones come from the rear parts of the animal; front limbs and components of the axial skeleton are not found in the material. 
Figure 11. The placement and possible positions of bodies in Salme boat. Drawing by Jaana Ratas. Boat contour from Konsa et al (2009), adapted.

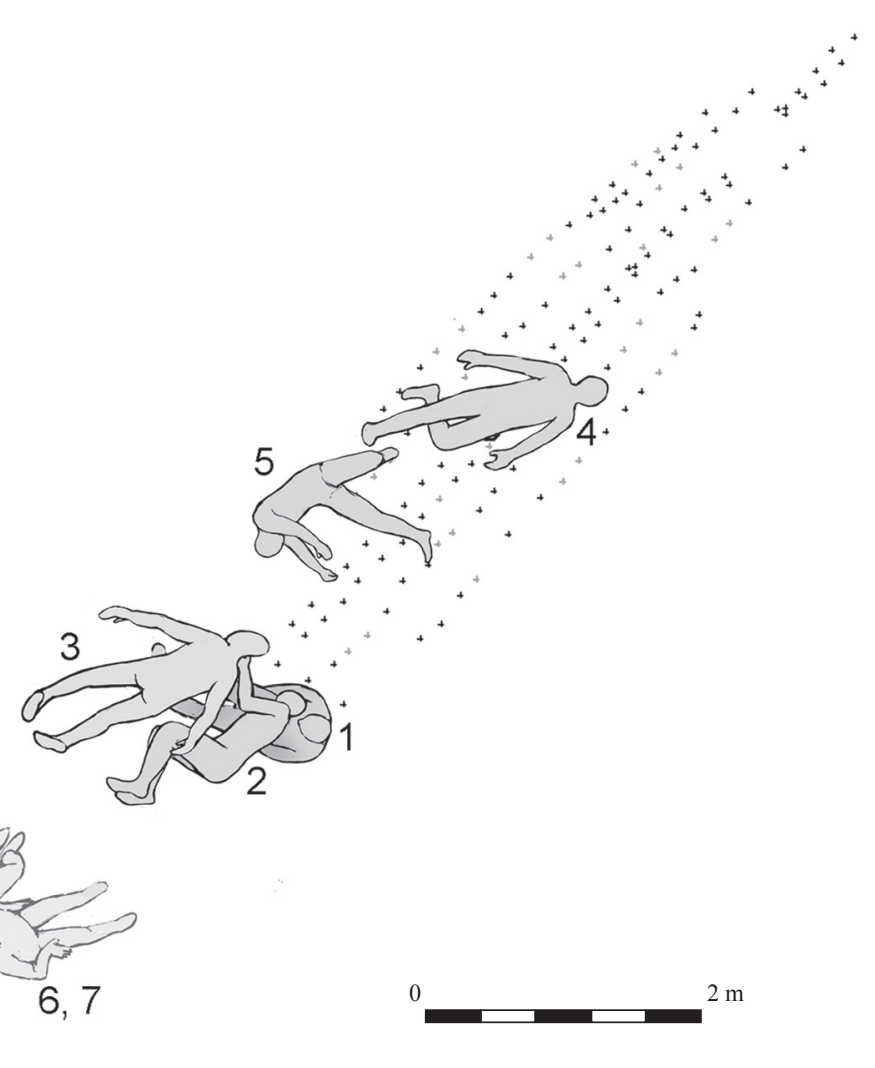

Hawk bones were located in quite clear assemblages in the bow (Figure 2). Goshawk bones, together with calf spondyls, were found on the port side, while sparrowhawk bones were to starboard near the centre. Goshawk bones recovered from the disturbed material were probably originally located in the same area but removed with the soil before archaeological excavations.

\section{Discussion}

Iron rivets have been found in about 40 prehistoric burial places in Estonia (Konsa et al. 2009). Three of them are thought to be ship burials, where the ship was cremated with human remains (Jaanits et al. 1982; Lang 2007). We cannot exclude the possibility that a ship-like construction, or parts of ships, were used in the funeral pyre instead of a working ship. On the other hand we do not know the details of the burial ritual and so we are unable to tell if ships and bodies were cremated at the burial place; and if they were not, we are also unable to tell how much of the cremated remains were carried to the burial site

In a sense the Salme ship is a typical ship grave comparable with those Vendel Era ship inhumations found in central Sweden. It certainly is the first such discovery in Estonia (Konsa 2008; Konsa et al. 2009), but with some remarkable features that distinguish it from Scandinavian examples. The whole assemblage of artefacts from the Salme ship is consistent with equipment required by armed seafarers (Konsa et al. 2009), including fast, light and easily manoeuvrable military vessels (Mäss 2008, 2009). Ornaments and household items like pottery are missing; at the same time some artefacts found in the Salme ship were unique among Estonian Middle Iron Age (450-800 AD) ones (Konsa et al. 2009). On the other hand, the construction of the ship exemplifies the technology used on the eastern coast of the Baltic Sea (Mäss 2008, 2009; Konsa et al. 2009). We suggest that the gaming pieces, knives, combs, meat, birds of prey, etc., could have been common equipment for seafarers of this period, and that the items were used in funeral rituals - should be ritual. In 550-800 AD inhumation was the prevailing burial custom for ship graves around the Baltic Sea (Müller-Wille 1974) and Scandinavian and Baltic contacts were established (Lundström 1983, 107) along with long-distance trade with areas to the east and south of the Baltic Sea by the $8^{\text {th }}$ century (Larsson 2007, 27).

There is a suggestion that the Salme ship burial was an emergency funeral ritual arranged for seafarers. In the light of this hypothesis the absence of the remains of dogs and horses, as well as the absence of horse harnesses, dog collars and chains and other household items - all very common in Swedish ship burials - is not surprising. The ship burials in Valsgärde, Vendel, Tuna in Alsike and Tuna in Badelunda are supposed to be upper class graves. The male graves of Vendel and Valsgärde suggest higher social status assumed from their rich grave goods (Arwidsson 1983; Schönbäck 1983; Liden et al. 2001). The men in the Valsgärde ship burials were called peasant landowners or peasant chieftains, who maintained 
their social standing generation after generation (Arwidsson 1983, 82). These people owned wealthy households, cattle, horses, dogs, and ships, although we cannot say if they used the ships themselves or hired professional seafarers for the work. They buried the dead with grave goods that manifested their wealth and status in the local community. In the case of Salme what we have is probably a funeral ritual arranged for a crew. The men died and were buried far from home. It might not be surprising that the horses, dogs and household items, very important in a wealthy person's grave, were absent in this burial. These items and animals could have been unnecessary or were unavailable, because none of these animals and items was part of the common equipment of seafarers.

In the Salme ship burial decapitated remains of goshawk and sparrowhawk were probably part of the funeral ritualbirds of prey have been found in the graves of wealthy Vendel and Viking Age people. However, the only known previous case where a bird of prey had been decapitated was a snowy owl (Nyctea scandiaca) found in burial 7 in Valsgärde (Arwidsson 1977, 19, 105). In burial 6 at Valsgärde the right tarsus of a goshawk was found (Arwidsson 1942, 109). In the Vendel III burial an eagle owl (Bubo bubo) was found beneath a cow's head in the south west part of the ship, and bones from a falcon were located amidships, slightly to the north east, close to the centreline of the ship (Stolpe, Arne $1912,20)$. Bones of birds of prey have been found in several cremation burials in Sweden: from Rickeby bones from an eagle owl, a sparrowhawk, a goshawk and two peregrines (Falco peregrinus). Goshawk remains have also been found in cremation burials in Uppland and Södermanland (Sjösvärd et al. 1983, 140-141).

Two types of falconry can be distinguished: high flight (waiting on) and low flight. In high flight the hawk takes its place high in the air waiting for prey to be roused by dogs. In low flight, the falconer walks or rides on horseback with his bird on the fist in search of prey. A dog may rouse the game, but low flight can be practised without a dog. This type of hawking is especially suited to woodland, and it is the only method used with goshawk and sparrow-hawk (Prummel 1997, 333-334). The mature female goshawk and sparrowhawk are larger than the male of the species and can catch larger game than male birds. For this reason they are better at supplying food for the table (Prummel 1997, 336). Both species found in the Salme ship burial are used for low flight hunting.

Falconry reached Europe from the steppes of Asia in the $3^{\text {rd }}-4^{\text {th }}$ centuries, the oldest written sources mentioning such way of hunting date from the $5^{\text {th }}$ century (Prummel 1997, 335). In Sweden the earliest find of hawk bones in a grave comes from Gamla Uppsala and was dated to before 500 AD. During the $6^{\text {th }}$ century the tradition of hawking was fully developed in Sweden. Bones of birds of prey in graves mainly occur in east Sweden, Uppland and Södermanland (Sten, Vretemark 1988, 153; Tyrberg 2002, 228-230) with the most frequent being goshawk finds (occurring in 27 of the 34 investigated graves, dating from 500-1000 AD)
(Tyrberg 2002, 228). At first birds of prey might have been taken to sea because hawking provided seafarers with fresh meat if needed. In addition, hawking might have been an amusement that helped seafarers to pass time, for example when waiting for favourable weather. The bones of goshawk and sparrowhawk among the bone material from the Salme ship burial are the earliest bone finds from Estonia that show evidence of falconry.

Nearly all of the Vendel and Viking Age ship burials from Valsgärde (Arwidsson 1942, 109-113; Arwidsson 1954, 120-121; Arwidsson 1977, 104-106; Fridell 1930), Vendel (Stolpe, Arne 1912), Årby (Arbman 1936a, 249-251), Tuna in Alsike (Arne 1934) and Gamla Uppsala (Nordahl 2001; Molnar 2001) contain horse and dog bones. In most cases, horses were found outside the ship on the starboard side, dogs within the ship near the port. These two species are also represented in Scandinavian ship graves (including burials containing large quantities of ship rivets, irrespective of cremation or inhumation) and in other regions, for example dog bones at Groß Strömkendorf in Germany (Gerds 2006, 155), Île de Groix, France (Price 1989, 66) and horse bones in the barrows at Gnezdovo, Russia (Duczko 2004, 162-170). On the basis of the investigations carried out in Sweden, various earlier cremation burials, as well as osteological material from chamber graves, strongly resemble ship burials in their archaeozoological material and the presence of dogs and horses (Lamm 1962, 292-293, tab. p. 295; Sjösvärd et al. 1983, 140; Arbman 1936b, 89-90). One of the basic differences between the species composition of archaeozoological material from the Salme complex and the ship burials of other regions is that dog and horse bones are absent.

Ship burials also contain numerous bones of other animals, particularly in the burials of the $7^{\text {th }}$ to $8^{\text {th }}$ centuries (Arwidsson 1942, 109-113; Arwidsson 1954, 121; Arwidsson 1977, 19, 104-106; Arwidsson 1983, 77; Kovalevskii 1956, 131-132, 141; Lamm 1962, 293; Loumand 2006, 131; Molnar 2001, 94; Sjösvärd et al. 1983, 140; Stolpe, Arne 1912, 20, 53, 58). They are largely domestic animals, as in the Salme I ship, including cattle, sheep/goats and pigs. These animals are found in ships as full and dismembered skeletons. The anatomical composition of the archaeozoological material from the Salme I ship is not particularly exceptional compared with the ship burials of Sweden. A somewhat surprising aspect is the complete absence of the distal ends of animal bones (starting from the distal row of carpal and tarsal bones), and the very low incidence of cranial bones (restricted solely to the cranium of a kid and canine of a sow).

Special mention should be made of the fact that the only fragments of animal skull found in the Salme ship belong to a kid. The Valsgärde 6 burial also contained the skull of a 3-4 week old kid (Arwidsson 1942, 109-113) while Valsgärde 7 contained the skull of an approximately 3-week old lamb (Arwidsson 1977, 105).

Sheep skulls have been found in several places. The Vendel III burial contained the skull of a young sheep while in Vendel XIV there was a sheep skull (Stolpe, Arne 1912, $20,58)$. In a grave in the Centralnaya group at Gnezdovo 
unburnt animal bones and an iron cauldron containing a ram head with horns, some wool and other artefacts were found beside a cremated ship burial (Duczko 2004, 165). The Olshanskii kurgan of the Olshanskaya group also contains a cremated ship burial with an uncremated sheep skull, a bird skeleton, and auroch bones (Duczko 2004, 170). It is difficult to say whether the lamb and sheep skulls are found in burials as meat or whether they possess some other meaning.

The Salme I ship burial is unique for the remarkable number of human burials inside the ship, and their sex ( 7 male burials). Furthermore, during archaeological investigations in Salme village in 2010 a new ship burial with 28 human skeletons was uncovered. 6 analysed skeletons in the first burial row were also male (Peets et al. 2011, 39-41). The number of exposed skeletons, their placement and the positions in the second ship burial as well the amount and type of grave goods are unique and distinct from those at the Salme I ship grave. Both burials are from the same time period: the end of the $7^{\text {th }}$, or the first half the $8^{\text {th }}$, century (Peets et al. 2011, 29).

So far only three ship burials/inhumations with greater than three sets of remains are known in northern Europe: the burials at Nabberör in Öland, Scar in Orkney and Kaupang in Norway (Graham-Campbell, Batey 1998, 139; Lamm 2002, 478: Stylegar 2007, 65-101). In these cases male and female individuals have been identified, and in Scar and Kaupang the remains of a child were found. The Naberrör ship grave from the Vendel era contains four burials. That amidships with several artefacts has been suggested as the central or main burial. The second in the bow and two others in the stern were less well equipped (Lamm 2002, 478) and it has even been suggested that they are sacrificed slaves (Anderbjörk in Hemmendorf 1984). The Kaupang richly furnished Viking age boat grave contained four burials: man, woman and baby were lying adjacent to each other; the second woman with high-status accoutrements was buried in the stern (Stylegar 2007, 95-100). The Viking Age boat burial at Scar contained three burials, all interred at the same time with typical grave goods. The woman had probably died in her seventies, the man in his thirties and the child at around 10 years of age (Graham-Campell, Batey 1998, 50, 138-140). The stature of the man was $181 \mathrm{~cm}$ (Graham-Campell, Batey 1998, 52). The men in the Salme ship were also quite tall, between 175 and $180 \mathrm{~cm}$, as is the case with some men from the $5^{\text {th }}$ to $7^{\text {th }}$ centuries in Läänemaa in Estonia (Allmäe 2003). Not much osteological information has been recovered from Scandinavian ship graves due to poor bone preservation. Unfortunately in many Swedish Vendel era ship graves with inhumations, the bones are badly preserved and sometimes totally absent, and the number of human burials in a ship is often unknown (Arwidsson 1983). The bone material in Tuna - Badelunda is extremely badly preserved. In Vendel and Valsgärde human bones are often absent and some animal bones are preserved. Only in Tuna - Alsike are both human and animal bones well preserved (Liden et al. 2001). The bone material in the Salme ship is quite well preserved despite several disturbances to the grave.
Do the placement and positions of human remains have any meaning? If whatever killed the men was an accident, did they die in these positions? If it is a burial we may propose that they were buried at their workstations. If the bodies were thrown into the ship without respect, their placement would be random. These are all hypotheses.

Can we exclude the highly romantic burial ritual described in Beowulf and in the myth of the death of Balder in which the corpses in the ship were pushed out to sea, beginning the journey to the afterlife (Schönbäck 1983, 124; OwenCrocker 2000)? Today we probably can because of the other ship burial from the same period found in the Salme area. This ship burial contained skeletal remains of 28 people and is different from Salme I ship burial in a number of ways: several skeletons had perimortal injuries on bones and nearly all men were buried with their weapons (Peets et al. 2011). Both vessels (the Salme I and Salme II) were pulled to shore and were lying more or less along a north east south west direction (Konsa et al. 2009; Peets et al. 2011). The common feature of both burial vessels is their placement on the shore and distance from the sea, which was close enough that storm waves certainly reached them. The vessels are buried under natural marine sediments by time, rather than by man (Konsa et al. 2009; Saarnisto in Peets et al. 2011, 33).

Could the men have died or been killed on these shores and buried with minimal respect and ritual? There is no evidence of violence found on the bones so far. The problem is also that we cannot even determine with certainty whether the corpses in the ship were covered with some sand and left on the shore, or whether storm waves covered the ship with sand and gravel. An intentional burial is of course more plausible, because of the ship's north east to south west axis with the prow pointing northwards as is commonly found in Swedish ship graves (Larsson 2007; Konsa et al. 2009). The decapitated birds of prey also point to a funeral ritual.

The first hypothesis is that the placement of bodies and their positions may relate to accidental death and/or some kind of emergency burial. The men of the crew, or some of them, could have died due to the hypothermia or other unknown causes, including infectious disease. The men died in the ship at their workstations and the burial ritual was conducted on the shore. The Salme ship was a military vessel with 6 pairs of oars (Mäss 2008, 2009). The minimum number of the crew should have been at least twelve men, if the ship moved by oar-power.

The second hypothesis is that bodies of men were buried in the ship at their workstations, perhaps in a sitting position. The mortuary practice of burying corpses in sitting positions has previously been suggested, as for example with the initial sitting position noted for two skeletons in the Nabberör ship burial (Lamm 2002, 478), some of the burials in Vendel (Stolpe, Arne 1912, 34, 53), and at Tuna in Alsike (Arne 1934). Unfortunately in the Salme ship burial most of the skeletons were destroyed, so a definite conclusion cannot be drawn. Some lower body parts survived only in S4, which may be because of the posited initial sitting position. As mentioned earlier, articulated skeletal material was quite 
scanty and not documented on site well enough to argue something definite concerning body positions in the ship, or to shed light on burial custom or its absence.

It is common knowledge in seafaring history that before 800 AD sail power was not used in northern Europe. Based on shipbuilding technology and construction details from the Salme ship, Vello Mäss (2008, 2009) has argued that the ship was an oar-powered ship, very similar to the Valsgärde 14 ship from $800 \mathrm{AD}$. A reconstruction of the Valsgärde 14 ship was carried out in 2001, producing a replica named the "Stefnir". "Stefnir is equipped with removable mast (http://skilfingarna. net/album.htm). There is some evidence that a sail mast and primitive sail were used before $800 \mathrm{AD}$ in Scandinavia. For example $5^{\text {th }}$ to $10^{\text {th }}$ century carved picture stones from Gotland in Sweden show several varieties of ships with sails. Earlier ships have only oars, while later examples (from the $6^{\text {th }}$ to $7^{\text {th }}$ centuries) may have been equipped with primitive sails. Later picture stones (from the $8^{\text {th }}$ and $10^{\text {th }}$ centuries) show ships with sails and rigging (Spurkland, van der Hoek 2005; Widerström, Norderäng 2004). We would like to draw attention to the placement and position of bodies in the Salme ship (Figure 11). If it was primarily a rowing ship, most of the men should have been buried or died at their workstations, generally facing the same direction; however, this is not the case. A good example from which to observe the placement of crew is the "Sotka", a modern replica of a Viking Age sail ship (http://www.viikinkiajanlaiva.net/). The placement of crew within the ship is quite different depending on whether the ship was under sail or under oar.

It is also noteworthy that the remains of the older men were found in the stern area of the Salme ship. It is known that older and more experienced men were responsible for steering or were skippers (tacticians). Schönbäck (1994 in Larsson 2007) has stated that in male ship burials the bodies were placed aft, a position associated with the captain or helmsmen. The remains of older men found in stern suggest that the placement of bodies was not random in the Salme ship.

There is some evidence showing that the location and positions of human remains in the ship are not random, however we have to agree that the construction of the ship is more suitable for oar-power than sailing (Mäss 2009). There are no archaeological facts to determine whether the Salme ship had a removable sail mast or not.

There is also no evidence of a covered area, such as a tent on board. There is a suggestion based on the Valsgärde grave field that the corpses were placed into the part of the ship which was used for sleeping, which was usually covered with a tent - commonly the stern was void of grave goods and human remains (Arwidsson 1983, 76). In the Salme ship the human bones were discovered from too wide an area to suggest that they were buried in the covered area of the ship.

The third hypothesis is that the corpses were just thrown into the ship without respect and some minor obligatory funeral rituals were conducted. The placement and position of the bodies does not exclude this possibility. On the other hand the absence of traces of violence on bones does not quite support this hypothesis. For example three skeletons out of six analysed from the second Salme ship burial indicated different blade wounds on the bones (Peets et al. 2011, 40-41). The bodies of men in the second Salme ship grave were buried with obvious care and respect (Peets et al. 2011). Different burial customs used for the deceased men in Salme the first and second ship could have been come from their different statuses or origins, or from events that took place in Salme village at the end of the $7^{\text {th }}$ or beginning of the $8^{\text {th }}$ centuries.

Compared with the Valsgärde and Vendel ship burials the location of animal bones in the Salme I ship is also slightly different. While in Sweden the animal bones were in the bow area of the ship, extending nearly amidships the animal bone finds at Salme (at least those documented during excavation) start about $2 \mathrm{~m}$ from the bow and definitely extend to the area damaged by the trench, i.e. to $2 / 3$ the length of the ship. Since the soil from the trench also contained animal bones and a few bone fragments were also recovered from the preserved stern, it is clear that animal bones could have occurred in larger or smaller assemblages all the way to the stern. There are two possible explanations of how animal bones got into the ship. The first option is based on the hypothesis that the Salme ship was involved in some accident and an emergency burial followed. Then we may assume that the men had meat with them as provisions. The second option is that the animal bones, or at least some of them, fell into the ship during the funerary ritual. Obviously we cannot distinguish provisional and sacrificed meat on the basis osteological finds.

\section{Conclusions}

The skeletal remains of seven men were found inside the $7^{\text {th }}$ to $8^{\text {th }}$ century Salme I ship burial on the island of Saaremaa, Estonia in 2008. Three men were over thirty years old and four were under thirty. Their stature was remarkable: between $175-182 \mathrm{~cm}$ according to all six measurable bones. All men suffered from periodontal disease, four had periodontal abscesses and one had a lesion caused by dental caries. New bone formation in tooth sockets and frequent periodontal abscesses may indicate scurvy, a disease very common in arctic and temperate regions of the northern hemisphere and for ancient seafarers.

The placement and positions of the bodies was reconstructed on the basis of photographs taken during construction and archaeological rescue excavations. All conclusions concerning the placement and initial positions of the bodies are somewhat speculative, as the skeletons were largely destroyed during previous construction and cabling activity. It is proposed that the placement of the bodies in the ship was not random. On one hand the placement and positions of the skeletons may indicate some kind of accidental death and emergency burial. On the other hand the burial of the bodies in sitting positions cannot be excluded. It is noteworthy that the remains of the older men were found in the stern area; more experienced seafarers were commonly skippers (tacticians) or responsible for steering. 
Animal bones were found within the preserved part of the ship as well as in the part destroyed by construction and the cable trench. Since no animal bones were found around the preserved part of the ship outside of its contour, nor in the profiles of the part destroyed by the trench further from the ship, we may assume that all the collected bones were initially located within the ship. Animals found include cattle (Bos taurus), sheep (Ovis aries), goat (Capra hircus), pig (Sus domestica), goshawk (Accipiter gentilis) and sparrowhawk (Accipiter nisus). The numbers of bone fragments of cattle, sheep and goat are more or less equal; hawk bones constitute about $7 \%$ of all identified bones. There are few pig bones. There are cattle bones from at least five or six individuals: two calves, one heifer, one heifer or young animal, and one or two adult animals. There are sheep and goat bones from at least ten individuals, including two lambs, three young animals butchered at 6-10 months, two butchered between 10 months and 3 years, and two adult animals. There are pig bones from at least two individuals, one of them aged below and the other above 3.5years. A peculiar feature in the anatomical composition of the bones is the absence of bones from the distal ends of limbs. Cranial bones are also almost completely missing - only the skull fragments, mandible and teeth of one kid were found, and from the trench area a sow canine. Hawks were placed in the ship beheaded. The animals were not placed in the ship as whole carcasses but rather the remains come from larger and smaller butchered pieces of meat. Chopping and cutting traces can be observed here and there on the bones. In the hawks no traces of dismembering, apart from beheading, were discovered.

In the light of archaeological and osteological information the Salme ship burial of the $7^{\text {th }}$ to $8^{\text {th }}$ centuries is an emergency burial of the crew of a military vessel. The whole assemblage of artefacts relates to the equipment needed by armed seafarers. The grave goods lack the household items, such as pottery, ornaments, horse harnesses, dogs and horses, which are characteristic to ship burials of the local elite in Sweden. Until the discovery of the Salme I ship burial knowledge was based mainly on Swedish ship burials in which spears, swords, gaming pieces, combs, meat and other items provide evidence for a burial ritual. We suggest that these items could have been the ordinary equipment of the crew of a military vessel; even the birds of prey could have been customary companions of the crew in maritime travel. The items and animals available were used in the emergency burial ritual for the crewmembers.

The number of buried bodies, the peculiarity of the composition of the animal bones and the archaeological evidence highlight the exceptional features of the Salme I ship grave in the context of northern Europe.

\section{Acknowledgements}

The study was undertaken in the framework of an Estonian government target funded research project (SF0130012s08) and was supported by research grants from the Estonian Science Foundation (№s 6899 and 7880).
The authors are deeply grateful to reviewers for their constructive criticism.

\section{References}

\section{Internet sources}

"Sotka" (The Lapuri Find) http://www.viikinkiajanlaiva.net/ 11. 12. 2011.

"Stefnir" (Replica of Valsgärde boat 14) http://skilfingarna.net/album.htm 11. 12. 2011.

MÄSS, V. 2008. Salme laevaleiu ehitustehnoloogiline interpretatsioon. http://lepo.it.da.ut.ee/ margek/Vello021208.pdf 11. 12. 2011.

\section{Literature}

ALEKSEJEV, V. P., DEBETS, G. F. 1964: Алексеев В. П., Дебец Г. Ф. 1964. Краниометрия. Методика антропологических исследований. Изд. Наука: Москва

ALLMÄE, R. 2003: Läänemaa 5.-13. sajandi kalmete antropoloogiline aines. In: Mandel, M. (Ed.): Läänemaa 5.-13. sajandi kalmed. Eesti Ajaloomuuseum, Tallinn, 243-262.

ANDERSON, G. 1963: Boat graves in Finland. In: Kivikoski, E. (Ed.): Suomen Museo LXX, Suomen Muinasmuistoyhdistys, Helsinki, 5-24.

ARBMAN, H. 1936a: Båtgrav vid Årby gård i Rasbokil socken, Uppland. Fornvännen 31, 249-251.

ARBMAN, H. 1936b: En kammargrav från vikingatiden vid Långtora, Uppland. Fornvännen 31, 89-98.

ARNE, T. J. 1934: Das Bootgräberfeld von Tuna in Alsike, Uppland. Kungliga Vitterhets Historie och Antikvitets Academien. Victor Pettersons bokindustriaktiebolag, Stockholm.

ARWIDSSON, G. 1942: Valsgärde 6. Die Gräberfunde von Valsgärde I. Acta Musei Antiquitatum Septentrionalium Regiae Universitatis Upsaliensis 1. Almqvist \& Wiksells, Uppsala.

ARWIDSSON, G. 1954: Valsgärde 8. Die Gräberfunde von Valsgärde II. Acta Musei Antiquitatum Septentrionalium Regiae Universitatis Upsaliensis 4. Almqvist \& Wiksells, Uppsala.

ARWIDSSON, G. 1977: Valsgärde 7. Die Gräberfunde von Valsgärde III. Acta Musei Antiquitatum Septentrionalium Regiae Universitatis Upsaliensis, 5. Uppsala.

ARWIDSSON, G. 1983: Valsgärde. In: Lamm, J. P., Nordström, H. Å. (Eds.): Vendel period studies. Transactions of the Boat-grave symposium in Stockholm, February 2-3, 1981. The Museum of National Antiquities, Stockholm Studies 2, 71-82.

BASS, W. 2005. Human osteology: A Laboratory and Field Manual. Missouri Archaeological Society, Missouri.

BOESSNECK, J., MÜLLER, H. H., TEICHERT, M. 1964. Osteologische Unterscheidungsmerkmale zwischen Schaf (Ovis aries Linné) und Ziege (Capra hircus Linné). Kühn Archiv 78, 1-129.

BRØGGER, A.V., FALK, H. J., SHETELIG, H. 1917: Osebergfundet I. Universitetets Oldsaksamling, Kristiania.

BROTHWELL, D. R. 1981: Digging up Bones. $3^{\text {rd }}$ ed. Oxford University Press, Oxford.

BRUCE-MITFORD, R. 1974: The Snape Boat-Grave. In: Aspects of AngloSaxon Archaeology - Sutton Hoo and other Discoveries. Gollancz, London.

BRUCE-MITFORD, R. L. S. 1978: The Sutton Hoo Ship-Burial: A Handbook. $3^{\text {rd }}$ ed. London.

BUIKSTRA, J. E., UBELAKER, D. (Eds.) 1994: Standards for Data Collection from Human Skeletal Remains. Proceedings of a Seminar at the Field Museum of Natural History. Arkansas Archaeological Survey Press, Fayetteville.

CARVER, M. O. H. (Ed.) 1992: The Age of Sutton Hoo: The Seventh Century in North-Western Europe. Woodbridge: Boydell Press

DUCZKO, W. 2004: Viking Rus: studies on the presence of Scandinavians in Eastern Europe. Brill: Leiden, Boston.

EVANS, A. C. 1986. The Sutton Hoo Ship Burial. British Museum, London.

FILMER-SANKEY, W. 1992: Snape Anglo-Saxon cemetery: the current state of knowledge. In: Carver, M. (Ed.): The Age of Sutton Hoo: The Seventh Century in North-Western Europe. Woodbridge: Boydell Press, 39-51. 
FRIDELL, A. 1930: Den första båtgraven vid Valsgärde i Gamla Uppsala socken. Förnvännen 25, 217-237.

GERDS, M. 2006: Scandinavian burial rites on the southern Baltic coast. Boat-graves in cemeteries of early medieval trading places. In: Andrén, A., Jennbert, K., Raudvere, C. (Eds.): Old Norse Religion in longterm perspectives: origins, changes and interactions: an international conference in Lund, Sweden, June 3-7, 2004. Nordic Academic Press, Lund, 153-158.

GERHARDS, G. 2000: Latvijas iedzivotaju kermena garuma izmainas pedejo divu gadu tukstošu laika. In: Zarina, G., Gravere, R. (Eds.): Latvijas Vēsturnieki. Antropologe profesore Dr. habil. Hist. LZA goda locekle Raisa Denisova. Latvijas Vestures Instituta Apgads, Riga, 55-72.

GRAHAM-CAMPBELL, J., BATEY, C. E. 1998: Vikings in Scotland: An Archaeological Survey. Edinburgh University Press, Edinburgh.

HEAPOST, L., THETLOFF, M. 1999: Eesti läänesaarte meeste kehamõõtude ajalised muutused. Eesti Antropomeetriaregistri aastaraamat 1999, $48-53$.

HEAPOST, L. 2002: Saarlaste antropoloogiast. In: Kään, H., Mardiste, H., Nelis, R., Pesti, O. (Eds.): Saaremaa 1, Eesti Entsüklopeediakirjastus, Tallinn, 557-594.

HEAPOST, L. 2003: Variation of the (sic) stature in Estonia from the 12th to the 20th centuries. Papers on Anthropology XII, 51-61.

HEMMENDORF, O. 1984: Människooffer. Et inslag i järnalderns gravritualer, belyst av et fynd i Bollstänas , Uppland. (A late Iron Age cremation burial with human sacrifice). Forvännen 79, 4-12.

JAANITS, L., LAUL, S., LÕUGAS, V., TÕNISSON, E. 1982: Eesti Esiajalugu. Valgus, Tallinn.

KOVALEVSKII, A. P. 1956. = Ковалевский А. П.: Книга Ахмеда ИбнФадлана и его путешествие на Волгу. Харьков.

KONSA, M. 2008: Самое древнее судно Эстонии. Baltfort: Balticmilitary history magazine, 4,83 .

KONSA, M., ALLMÄE, R., MALDRE, L.,VASSILJEV, J. 2009: Rescue excavations of a Vendel Era boat-grave in Salme, Saaremaa. Archaeological Fieldworks in Estonia 2008, 53-64.

LAMM, J. P. 1962: Ett vendeltida gravfynd från Spelvik. Fornvännen 57, 277-299.

LAMM, J. P. 2002: Nabberör. In: Beck, H., Geuenich, D., Steuer, H. (Eds.): Reallexikon der germanischen Altertumskunde. Zweite Auflage, Band 20, De Gruyter, 478-479.

LANG,V. 2007: Baltimaade pronksi- ja rauaaeg. Tartu Ülikooli Kirjastus, Tartu.

LARSSON, G. 2007: Ship and society. Maritime Ideology in Late Iron Age Sweden. Aun 37, Uppsala.

LIDEN, K., ISAKSSON, S., GÖTHERSTRÖM, A. 2001: Regionality in the boat-grave cemeteries in lake Mälaren valley. In: Arrhenius, B. (Ed.): Kingdoms and regionality. Transactions from the 49th Sachsensymposium 1998 in Uppsala. Theses and papers in archaeology B:6. Archaeological Research Laboratory, University of Stockholm, 27-40.

LOUMAND, U. 2006: The horse and its role in Icelandic burial practices, mythology and society. In: Andrén, A., Jennbert, K., Raudvere, C. (Eds.): Old Norse Religion in long-term perspectives: origins, changes and interactions: an international conference in Lund, Sweden, June 3-7, 2004. Nordic Academic Press, Lund, 130-134.

LUNDSTRÖM, A. 1983: Vendel and Vendel period. In: Lamm, J. P., Nordström, H. Å. (Eds.): Vendel period studies. Transactions of the Boatgrave symposium in Stockholm, February 2-3, 1981. The Museum of National Antiquities, Stockholm Studies 2, 104-108.

MAAT, G. 2004: Scurvy in Adults and Youngsters: Dutch Experience. A Review of the History and Pathology of Disregarded Disease. International Journal of Osteoarchaeology 14, 77-81.

MAYS, S. 2006: The Archaeology of Human Bones. London, New York.

MILES, A. E. W. 1963: The Dentition in the Assessment of Individual Age in Skeletal Material. In: Brothwell, D. R. (Ed.): Dental Anthropology. Pergamon, Oxford, 191-209.

MOLNAR, P. 2001: Osteologiska analyser. In: Nordahl, E. Båtgravar $i$ Gamla Uppsala. Spår av en vikingatida högreståndsmiljö. Aun 29, 93-97, Uppsala.

MÄGI, M. 2007: Archaeological excavations at Viltina - a Viking Age harbour site and meeting place. Arheoloogilised välitööd Eestis = Archeological fieldwork in Estonia 2006, 121-134.
MÄSS, V. 2009: Salme laevaleiu teaduslikust, kultuurilisest ja tunnetuslikust aspektist. Eesti Merelaevanduse Aastaraamat, Tallinn, 146-149.

MÜLLER-WILLE, M. 1974: Boat-graves in northern Europe. The International Journal of Nautical Archeology and Underwater Exploration 3(2), 187-204.

NICOLAYSEN, N. 1882: Langskibet Fra Gokstad Ved Sandefjord. The viking ship discovered at Gokstad in Norway. Alb. Cammermeyer, Christiania.

NORDAHL, E. 2001: Båtgravar i Gamla Uppsala. Spår av en vikingatida högreståndsmiljö. Aun 29, Uppsala.

NORDERÄNG, J., WIDERSTRÖM, P. 2004: The picture stones of Gotland. Minerva, Vol 15, No 5. London.

OWEN-CROCKER, G. R. 2000: The four funerals in Beowulf: and the structure of the poem. Manchester University Press, Manchester.

PEETS, J., ALLMÄE, R., MALDRE, L. 2011: Pre-Viking Age complex of burial boat in Salme village. Archaeological investigations in 2010. Archaeological Fieldwork in Estonia 2010, 29-48.

PEETS, J., MALDRE, L. 2010: Salme paadijäänused ja luunupud. In: Tamla, Ü.(Ed.): Ilusadasjad. Tähelepanuväärseidleide Eestiarheoloogiakogudest. Muinasaja teadus 21. Ajaloo Instituut, Tallinn, 47-88.

PRICE, N. S. 1989: The Vikings in Brittany. Viking Society for Northern Research, University College London.

PRUMMEL, W. 1997: Evidence of Hawking (Falconry) from Bird and Mammal Bones. International Journal of Osteoarchaeology 7, 333-338.

PULSIANO, P., WOLF, K. (Eds) 1993:Medieval Scandinavia: an encyclopedia. Garland, New york, 238.

ROBERTS, C.A., MANCHESTER, K. 1995: The Archaeology of Disease. $2^{\text {nd }}$ edition. Sutton Publishing, Stroud.

RUNDKVIST, M., WILLIAMS, H. 2008: A Viking Boat Grave with Amber Gaming Pieces Excavated at Skamby, Östergotland, Sweden. Medieval Archaeology 52.

SCHMID, E. 1972: Atlas of Animal Bones. Amsterdam, London, NewYork.

SCHÖNBÄCK, B. 1983: The custom of burial in boats. In: Lamm, J. P., Nordström, H. Å. (Eds.): Vendel Period Studies. Transactions of the Boat-grave symposium in Stockholm, February 2-3, 1981. The Museum of National Antiquities, Stockholm Studies 2, 123-132.

SILVER, I. A. 1969: The ageing of domestic animals. In: Brothwell, D., Higgs, S. (Eds.): Science in Archaeology. London, 283-302.

SJÖSVÄRD, L., VRETEMARK, M., GUSTAFSSON, H. 1983: A Wendel warrior from Vallentuna. In: Lamm, J. P., Nordström, H. Å. (Eds.): Vendel period studies. Transactions of the Boat-grave symposium in Stockholm, February 2-3, 1981. The Museum of National Antiquities, Stockholm Studies 2, 133-150.

SORENSEN,A., BISCHOFF, V., JENSEN, K. 2001: Land By: A Danish Ship-Grave from the Viking Age. Viking Ship Museum/National Museum of Denmark, USA.

SPURKLAND, T., VAN DER HOEK, B. (transl.) 2005: Norwegian runes and runic inscriptions. Boydell Press, Woodbridge.

STEN, S., VRETEMARK, M. 1988: Storgravsprojektet - osteologiska analyser av yngre järnålderns benrika brandgravar. Fornvännen 83, $145-156$.

STOLPE, H., ARNE, T. J. 1912: Graffältet vid Vendel. Kungliga Vitterhets Historie och Antikvitets Academien. Beckmans Boktryckeri, Stockholm.

STYLEGAR, F.-A. 2007: The Kaupang cemeteries revisited. In: D. Skre (Ed.): Kaupang in Skiringssal. Kaupang Excavation Project Publication Series 1, Aarhus University Press, Århus, 65-128.

TROTTER, M., GLESER, G. C. 1952: Estimation of stature from long bones of American Whites and Negroes. American Journal of Physical Anthropology 16 (1), 463-514.

TYRBERG, T. 2002: The archaeological record of domesticated and tamed birds in Sweden. Acta zooloogica cracoviensia 45 (special issue), 215-231.

UBELAKER, D. H. 1978: Human Skeletal Remains: Excavation, Analysis, Interpretation. Taraxacum, Chicago.

WORKSHOP OF EUROPEAN ANTHROPOLOGISTS (WEA) 1980: Recommendations for Age and Sex Diagnoses of Skeletons. Journal of Human Evolution 9, 517-549.

WESTERDAHL, C. 1985: Sewn boats of the North: A preliminary catalogue with introductory comments. Part 1. The International Journal of Nautical Archaeology and Underwater Exploration 14(1), 33-62. 